\title{
Activity of phytochemical constituents of Curcuma longa (turmeric) and Andrographis paniculata against coronavirus (COVID-19): an in silico approach
}

\author{
Kalirajan Rajagopal' $\mathbb{D}^{*}$, Potlapati Varakumar, Aparma Baliwada and Gowramma Byran
}

\begin{abstract}
Background: In early 2020, many scientists are rushing to discover novel drugs and vaccines against the coronavirus, and treatments for COVID-19, because coronavirus disease 2019 (COVID-19), a life-threatening viral disease, affected first in China and quickly spread throughout the world. In this article, in silico studies have been performed to explore the binding modes of chemical constituents for natural remedies like Curcuma longa (turmeric) and Andrographis paniculata against COVID-19 (PDB ID 5R82) targeting coronavirus using Schrodinger suit 2019-4. The molecular docking studies are performed by the Glide module, in silico ADMET screening was performed by the QikProp module, and binding energy of ligands was calculated using the Prime MM-GB/SA module.

Results: The chemical constituents from turmeric like cyclocurcumin and curcumin and from Andrographis paniculata like andrographolide and dihydroxy dimethoxy flavone are significantly binding with the active site of SARS CoV-2 main protease with Glide score more than -6 when compared to the currently used drugs hydroxychloroquine (5.47) and nelfinavir (-5.93). When compared to remdesivir $(-6.38)$, cyclocurcumin from turmeric is significantly more active. The docking results of the compounds exhibited similar mode of interactions with SARS CoV-2. Main protease and the residues THR24, THR25, THR26, LEU27, SER46, MET49, HIE41, GLN189, ARG188, ASP187, MET165, HIE164, PHE181, and THR54 play a crucial role in binding with ligands.

Conclusion: Based on in silico investigations, the chemical constituents from turmeric like cyclocurcumin and curcumin and from Andrographis paniculata like andrographolide and dihydroxy dimethoxy flavone, significantly binding with the active site of SARS CoV-2 main protease, may produce significant activity and be useful for further development.
\end{abstract}

Keywords: Coronavirus (COVID-19), Curcuma longa (turmeric), Andrographis paniculata, Docking studies, MM-GBSA

\section{Background}

Coronavirus disease 2019 (COVID-19) is a life-threatening disease which was affected first in China and quickly spread throughout the world [1-6]. According to the WHO data, as of the second week of April 2020, there are 21.5 lakhs peoples in the world affected by COVID-19, out of these more than 1.5 lakhs peoples died. With more asymptomatic

\footnotetext{
* Correspondence: rkalirajan@ymail.com; rkalirajan@jssuni.edu.in Department of Pharmaceutical Chemistry, JSS College of Pharmacy (A constituent college of JSS Academy of Higher Education \& Research-deemed University), Ooty, The Nilgiris, Tamilnadu 643001, India
}

infections being found among COVID-19 cases, it is worthy of consideration the detailed current evidence and understanding of the transmission of SARS CoV, MERS-CoV, and SARS CoV-2 and discussion on pathogen inactivation methods on coronaviruses is very important [7-12].

In this emergency situation, it is very difficult to discover novel drugs with all clinical trials and also determine the side effects, adverse effects, etc. So, it is important to find some natural remedies for the prevention and treatment of COVID-19. From the literatures, the natural products like Curcuma longa (turmeric) and Andrographis
Springer Open
() The Author(s). 2020 Open Access This article is licensed under a Creative Commons Attribution 4.0 International License, which permits use, sharing, adaptation, distribution and reproduction in any medium or format, as long as you give appropriate credit to the original author(s) and the source, provide a link to the Creative Commons licence, and indicate if changes were made. The images or other third party material in this article are included in the article's Creative Commons licence, unless indicated otherwise in a credit line to the material. If material is not included in the article's Creative Commons licence and your intended use is not permitted by statutory regulation or exceeds the permitted use, you will need to obtain permission directly from the copyright holder. To view a copy of this licence, visit http://creativecommons.org/licenses/by/4.0/. 
Table 1 Docking studies for phytochemical constituents of Curcuma longa (turmeric) and Andrographis paniculata with SARS CoV-2 main protease (5R82)

\begin{tabular}{lllllllll}
\hline Cpd & Glide score & $\begin{array}{c}\text { Lipophilic } \\
\text { EvdW }\end{array}$ & Phob En & H bond & XP electro & Low MW & Rot Penal & XP penalties \\
\hline T4_Cyclocurcumin & -6.77 & -4.12 & 0 & -2.36 & -0.35 & -0.27 & 0.18 & 0 \\
N1_Andrographolide & -6.26 & -1.27 & 0 & -4.01 & -1.3 & -0.33 & 0.2 & 0 \\
N7_dihydroxydimethoxyflavone & -6.23 & -2.69 & 0 & -2.44 & -0.84 & -0.45 & 0.08 & 0 \\
T1_Curcumin & -6.13 & -4.14 & 0 & -1.46 & -0.72 & -0.27 & 0.37 & 0 \\
T3_Bisdemethoxycurcumin & -5.36 & -4.13 & 0 & -0.7 & -0.6 & -0.47 & 0.5 & 0 \\
T2_Demethoxycurcumin & -5.25 & -3.69 & 0 & -1.06 & -0.62 & -0.37 & 0.42 & 0 \\
T7_Curcuphenol & -5.13 & -4.34 & 0 & -0.7 & -0.31 & -0.5 & 0.6 & 0 \\
N3_14deoxy12hydroxyandrographolide & -5.11 & -2.89 & 0 & -2.12 & -0.27 & -0.33 & 0.27 & 0 \\
T6_Curlone & -3.89 & -4.05 & 0 & 0 & -0.07 & -0.5 & 0.6 & 0 \\
N2_14deoxyandrographolide & -3.88 & -1.96 & 0 & -2.07 & -0.54 & -0.39 & 0.29 & 0 \\
T5_Turmerone & -3.78 & -3.87 & 0 & 0 & -0.01 & -0.5 & 0.6 & 0 \\
N8_cinnamateester & -3.31 & -3.55 & 0 & 0 & -0.02 & -0.5 & 0.76 & 0 \\
N5_Stigmasterol & -2.28 & -3.6 & 0 & 0 & 0.02 & -0.12 & 0.15 \\
N6_ßSitosterylfattyacidesters & -1.89 & -2.66 & 0 & -0.3 & -0.02 & 0 & 0.32 & 0 \\
N4_betaSitosterol & -1.36 & -1.86 & 0 & 0 & -0.06 & -0.12 & 0.2 \\
Hydroxychloroquine (Std) & -5.47 & -3.15 & 0 & -1.75 & -0.69 & -0.38 & 0.5 & 0 \\
\hline
\end{tabular}

Table 2 In silico ADMET screening for phytochemical constituents of Curcuma longa (turmeric) and Andrographis paniculata

\begin{tabular}{lllllllll}
\hline Compounds & Mol. Wt. & Dipole & Donor HB & Accpt HB & QPlog o/w & \#metab & Rule of five & \%Human oral absorption \\
\hline T1_Curcumin & 368.385 & 8.366 & 2 & 7 & 3.301 & 5 & 0 & 88.976 \\
T2_Demethoxycurcumin & 338.359 & 9.291 & 2 & 6.25 & 2.821 & 4 & 0 & 85.615 \\
T3_Bisdemethoxycurcumin & 308.333 & 8.477 & 2 & 5.5 & 2.585 & 3 & 0 & 81.091 \\
T4_Cyclocurcumin & 368.385 & 5.335 & 2 & 5.75 & 3.488 & 6 & 0 & 90.504 \\
T5_Turmerone & 218.338 & 3.649 & 0 & 2 & 4.036 & 6 & 0 & 100 \\
T6_Curlone & 218.338 & 3.147 & 0 & 2 & 3.991 & 5 & 0 & 100 \\
T7_Curcuphenol & 218.338 & 1.472 & 1 & 0.75 & 4.419 & 6 & 0 & 100 \\
N1_Andrographolide & 350.454 & 6.319 & 3 & 8.1 & 1.455 & 6 & 0 & 77.655 \\
N2_14deoxyandrographolide & 334.455 & 4.004 & 2 & 6.4 & 2.46 & 6 & 0 & 91.184 \\
N3_14deoxy12OH_andrographolide & 350.454 & 4.508 & 2 & 7.1 & 2.04 & 6 & 0 & 83.156 \\
N4_betaSitosterol & 414.713 & 2.542 & 1 & 1.7 & 7.643 & 3 & 1 & 100 \\
N5_Stigmasterol & 412.698 & 2.464 & 1 & 1.7 & 7.473 & 5 & 1 & 100 \\
N6_BSitosterylfattyacidesters & 526.885 & 3.304 & 0 & 2 & 9.625 & 3 & 2 & 100 \\
N7_dihydroxydimethoxyflavone & 314.294 & 3.726 & 1 & 4.5 & 2.682 & 4 & 0 & 93.829 \\
N8_cinnamateester & 218.295 & 4.054 & 0 & 2 & 3.983 & 0 & 0 & 100 \\
Hydroxychloroquine (std) & 335.876 & 6.854 & 2 & 5.7 & 3.369 & 5 & 0 & 93.213 \\
Recommended values & $130-725$ & $1-12.5$ & $0-6$ & $2-20$ & $-2-6.5$ & $1-8$ & max 4 & $>80 \%$ is high \\
& & & & & & & $25 \%$ is poor
\end{tabular}

Mol. Wt. molecular weight of the molecule, Dipole computed dipole moment, Donor HB estimated number of hydrogen bonds that would be donated by the solute to water molecules in an aqueous solution, Accpt $H B$ estimated number of hydrogen bonds that would be accepted by the solute from water molecules in an aqueous solution, QPlog o/w predicted octanol/water partition coefficient, \#metab number of likely metabolic reactions, Rule of five number of violations of Lipinski's rule of five, \%Human oral absorption predicted human oral absorption on 0 to $100 \%$ scale 
paniculata were reported for various biological activities and used traditionally for curing many diseases. Also, there is no or minimum side effects reported when compared to allopathic drugs.

The dried and powdered root Curcuma longa (turmeric) is belonging to the Zingiberaceae family, which is being cultivated in many countries worldwide. It has many uses such as textile dyes, herbal medicines, or food products. The biological properties of its chemical components were reported for inhibition of platelet aggregation [13], anti-diabetic [14], anti-tumor [15-17], anti-inflammatory effects [18], antioxidant effects [19], anti-platelet aggregation effects [20], gastroprotective effects [21], lipid-lowering effects [22], Alzheimer's effects [23], etc.

Andrographis paniculata was reported for the treatment of liver diseases [24], fever, common cold [25], acute diarrhea [26], hypertension [27], chicken pox, leprosy [28], hepatitis [29], malaria [30], anti-inflammatory effects [31], anti-cancer [32], diabetes [33], etc.

As part of our ongoing research on searching the potent biological molecules against various diseases by in silico and wet lab methods [34-44], we have designed and evaluated various heterocyclic compounds for their biological activities. Using different modules (Glide, QikProp, and Prime) of Schrödinger suite LLC various computational methods like molecular docking, ADMET screening, and bindingfree energy, calculations were performed to find the interactions responsible for SARS CoV-2 main protease inhibition. These studies will provide the requirement of key structural features in the design of potential drug candidates.

\section{Methods}

The 3D crystal structure of COVID-19 protein called SARS CoV-2 main protease receptor co-crystallized with 6-(ethylamino) pyridine-3-carbonitrile (PDB ID 5R82, resolution $1.31 \AA$ ) was retrieved from the protein data bank. The protein was prepared using the protein preparation wizard of epic module of Schrödinger suite 2019-4. The protein structure retrieved from the RCSB protein data bank is a monomer with co-crystallized ligand. The protein was prepared by using the protein preparation wizard by refining bond orders, addition of hydrogens, and deleting water molecules beyond $5 \AA$, and missing chains are included by using the Prime module [45] of Schrödinger suite 2019-4. Protein minimization was performed using optimized potentials for liquid simulations (OPLS3) molecular force field with RMSD of crystallographic heavy atoms kept at $0.30 \AA$. A grid box was generated to define the centroid of the active site. All the compounds were docked into the catalytic pocket of SARS CoV-2 main protease by using the Glide module of Schrödinger suite 2019-4 in extra precision (XP) mode [46]. The ligands with significant Glide scores have more binding affinity towards SARS CoV-2 main protease enzyme. To predict the free energy of binding for the set of ligands in complex with a receptor, post-docking energy minimization studies were performed using Prime molecular mechanics-generalized Born surface area (MM-GB/SA) of Schrödinger 2019-4. The energy for minimized XP docked pose of ligand-receptor complex was calculated using the OPLS3 force field and generalized Born/surface area $(\mathrm{GB} / \mathrm{SA})$ continuum VSGB 2.0 solvent model $[47,48]$.

Table 3 Binding free energy calculation using Prime/MM-GBSA approach

\begin{tabular}{|c|c|c|c|c|c|c|}
\hline Compd & MMGBSA_dG_Bind & $\begin{array}{l}\text { MMGBSA } \\
\text { _dG_Bind_ } \\
\text { Coulomb }\end{array}$ & $\begin{array}{l}\text { MMGBSA } \\
\text { _dG_Bind__ } \\
\text { Covalent }\end{array}$ & $\begin{array}{l}\text { MMGBSA_dG_Bind } \\
\text { Hbond }\end{array}$ & $\begin{array}{l}\text { MMGBSA } \\
\text { _dG_Bind__ } \\
\text { Lipo }\end{array}$ & MMGBSA_dG_Bind_vdW \\
\hline T4_Cyclocurcumin & -36.0315 & -31.6404 & 8.0570 & -0.1385 & -11.6120 & -28.1951 \\
\hline N1_Andrographolide & -34.6766 & -28.4227 & 6.9893 & -1.9077 & -4.4014 & -28.5162 \\
\hline N7_diOHdiOMeflavone & -50.6953 & -41.1895 & 1.6877 & -1.5594 & -8.5302 & -26.2631 \\
\hline T1_Curcumin & -50.3408 & -18.0802 & 1.5801 & -2.6563 & -11.9153 & -42.2597 \\
\hline T3_BisdeOMecurcumin & -43.5559 & -22.2542 & -1.599 & 0.5231 & -11.2505 & -35.4184 \\
\hline T2_Demethoxycurcumin & -38.7071 & -9.1482 & 6.6291 & -1.3511 & -11.0807 & -42.2478 \\
\hline T7_Curcuphenol & -26.1402 & -11.4548 & 14.9959 & 0.0274 & -17.0435 & -27.3193 \\
\hline N3_14deoxy12OHandrographolide & -29.3622 & -5.8525 & -9.0786 & 0.1215 & -10.4797 & -33.9966 \\
\hline T6_Curlone & -22.3669 & -23.7502 & 2.6632 & -0.3572 & -9.3057 & -17.1282 \\
\hline N2_14deoxyandrographolide & -39.6148 & -17.6018 & 7.7512 & -1.4333 & -14.1630 & -35.8594 \\
\hline T5_Turmerone & -24.1033 & 14.8710 & -12.9950 & 3.1283 & -8.2392 & -37.1469 \\
\hline N8_cinnamateester & -30.7961 & 6.1548 & 1.5202 & 0.4830 & -10.6485 & -41.1941 \\
\hline N5_Stigmasterol & -31.5416 & 18.6211 & -6.1436 & 2.5054 & -15.3476 & -41.7355 \\
\hline N6_ßSitosterylfattyacidesters & 1.1272 & 27.1428 & -0.7667 & 3.0617 & -5.4991 & -29.3366 \\
\hline N4_betaSitosterol & -25.0588 & -5.7182 & 1.8587 & 1.9414 & -10.8267 & -31.8647 \\
\hline Hydroxychloroquine (std) & -26.9975 & -4.9621 & 2.1824 & 0.0011 & -9.2894 & -33.0622 \\
\hline
\end{tabular}


a Chemical-structuresofselectedmajorbioactiveconstituents Curcuma longa (Turmeric)<smiles>CC(C)=CC(=O)CC(C)C1C=CC(C)=CC1</smiles>

Turmerone<smiles>C=C1C=CC(C(C)CC(=O)C=C(C)C)CC1</smiles>

Curlone<smiles>CC(C)=CCCC(C)c1ccc(C)cc1O</smiles>

Curcuphenol<smiles>COc1cc(/C=C/C(=O)CC(=O)/C=C/c2ccc(O)c(OC)c2)ccc1O</smiles><smiles>COc1cc(/C=C/C(=O)CC(=O)/C=C/c2ccc(O)cc2)ccc1O</smiles><smiles>O=C(/C=C/c1ccc(O)cc1)CC(=O)/C=C/c1ccc(O)cc1</smiles>

Bisdemethoxycurcumin (BDMC)<smiles>COc1cc(/C=C/C2=CC(=O)C[C@H](c3ccc(O)c(OC)c3)O2)ccc1O</smiles>

b Chemical structures of selected major bioactive constituents of Andrographis paniculata (Burm.f.) Nees<smiles>C=C1CCC2C(C)(CO)[C@H](O)CC[C@@]2(C)[C@@H]1C/C=C1\C(=O)OC[C@H]1O</smiles>

N1_Andrographolide<smiles>CCC(CCC(C)C1CCC2C3CCC4CC(O)CCC4(C)C3CCC12C)C(C)C</smiles>

N4_betaSitosterol<smiles>COc1cc(O)c2c(=O)cc(-c3ccccc3O)oc2c1OC</smiles>

N7_dihydroxydimethoxyflavone<smiles>C=C1CCC2C(C)(CO)C(O)CCC2(C)[C@H]1CCC1=CCOC1=O</smiles>

N2 14deoxyandrographolide

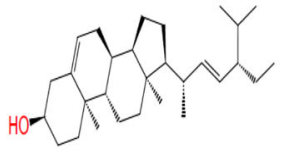

N5_Stigmasterol<smiles>CCCCCOC(=O)/C=C/c1ccccc1</smiles>

N8_cinnamateester<smiles>C=C1CCC2C(C)(CO)[C@@H](O)CC[C@]2(C)[C@H]1CC(O)C1=CCOC1=O</smiles>

N3_14deoxy12-OHandrographolide

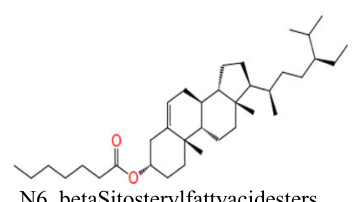

c

structure of Hydroxychloroquine (Std)<smiles>CCN(CCO)CCC[C@H](C)Nc1ccnc2cc(Cl)ccc12</smiles>

Fig. 1 Structures of phytochemical constituents. a Chemical structures of selected major bioactive constituents of Curcuma longa (turmeric). $\mathbf{b}$ Chemical structures of selected major bioactive constituents of Andrographis paniculata (Burm.f.) Nees. c Structure of hydroxychloroquine (Std) 


\section{Results}

Results are summarized in Tables 1, 2, and 3 and Figs. 1, $2,3,4,5,6$, and 7 . The results revealed that the SARS $\mathrm{CoV}-2$ main protease inhibitory property of the compounds isolated from some natural products like Curcuma longa (turmeric) and Andrographis paniculata greatly depended on the chemical nature of the substituents. The chemical structures of selected major bioactive constituents of Curcuma longa (turmeric) and Andrographis paniculata are given in Fig. 1a and b. The anti-malarial drug which was currently recommended in many countries like the USA, India, etc. [49] for the treatment of COVID-19 is hydroxychloroquine (Fig. 1c).

The docking studies of the ligands to protein active sites were performed by an advanced molecular docking program Glide module of Schrodinger suite 2019 Maestro-12.2 version for determining the binding affinities of the compounds. The designed analogues were docked towards the SARS CoV-2 main protease (PDB ID 5R82) in order to ascertain their inhibitory activity. The analogues show best fit root mean square difference (RMSD) value of 0.2 .

The results are summarized in Table 1. Almost all the compounds are docked in the same binding pocket.

The 2D-ligand interaction diagrams of T4_Cyclocurcumin, N1_Andrographolide, N7_dihydroxydimethoxyflavone, and T1_Curcumin with SARS CoV-2 main protease (PDB ID 5R82) are given in Fig. 3a-d. The 2D-ligand interaction diagram of hydroxychloroquine is given in Fig. 3e.
From the molecular docking study, it was revealed that the ligands have shown agreeable Glide $G$ score values from - $6.13 \mathrm{kcal} / \mathrm{mol}$ (T1_Curcumin) to $-6.77 \mathrm{kcal} / \mathrm{mol}$ (T4_Cyclocurcumin) when compared to the currently recommended drugs for COVID-19 hydroxychloroquine (G score -5.47$)$ and nelfinavir $(-5.93)$. When compared to remdesivir $(-6.38)$, cyclocurcumin from turmeric is significantly more active. From the obtained binding modes, it was illustrated that the ligands formed hydrophobic interactions and hydrogen bonding interactions with different residues THR24 to GLN192 surrounding the active pocket which was shown in Fig. 4. The ligand N1_Andrographolide exhibited hydrogen bonding interaction with some amino acid residues and with some water molecules which are shown in Fig. 5 . The presence of aromatic features and different heterocyclic rings majorly contributed towards lipophilic factors (Fig. 6).

The Glide score of the standard compound hydroxychloroquine was decreased because of the rotational penalty of the side alkyl chain which was shown in Fig. 7.

Molecular docking was additionally assessed with MMGBSA free restricting vitality which is identified with the post-scoring approach for SARS CoV-2 main protease (PDB ID 5R82) target and the values are shown in Table 3.

\section{Discussion}

From the docking results, as shown in Table 1, it is clearly demonstrated that some of the chemical constituents from turmeric like cyclocurcumin and curcumin and from Andrographis paniculata like andrographolide and dihydroxy

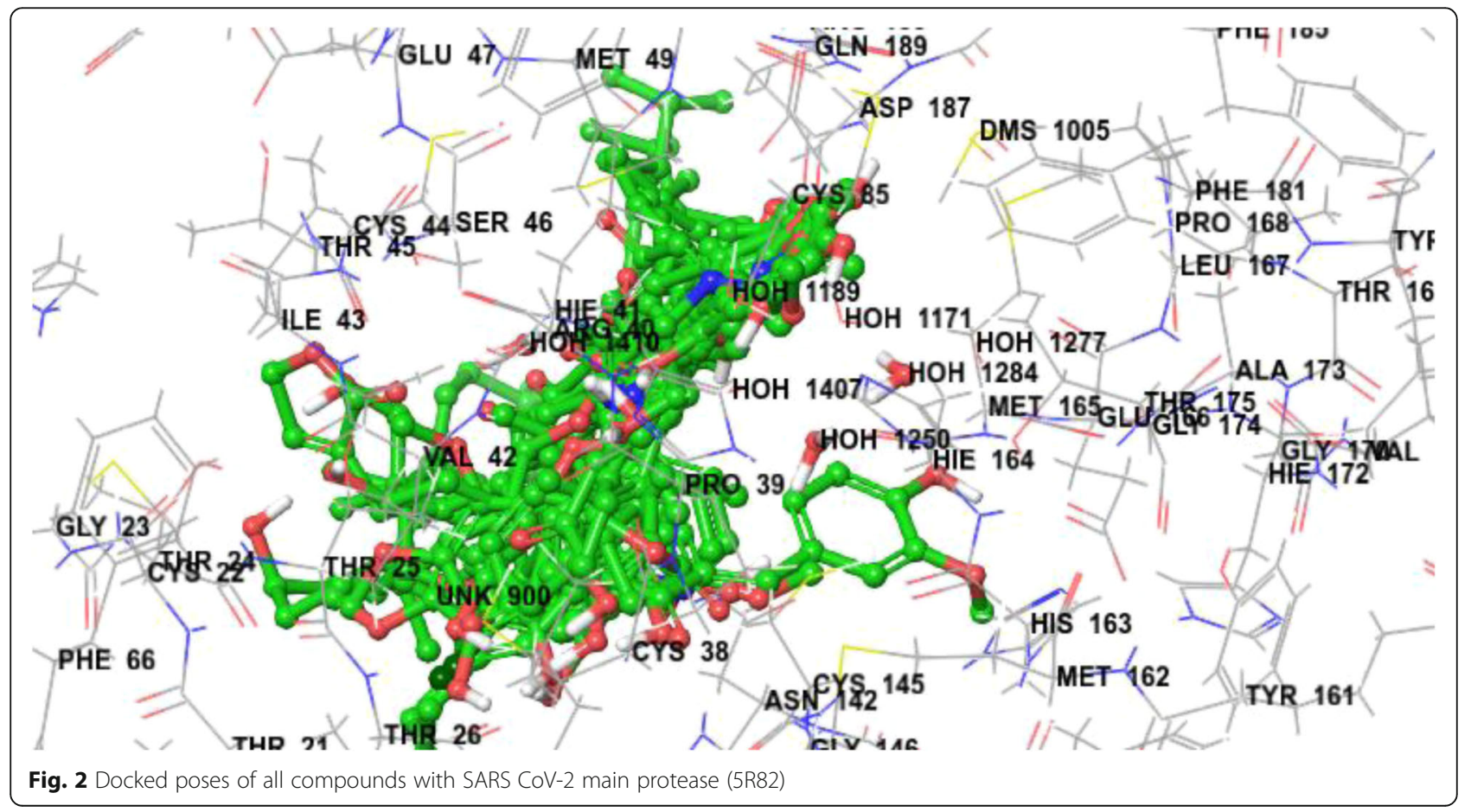


a Ligand Interaction of compound T4 Cyclocurcuminwith SARS CoV-2 main protease (5R82)

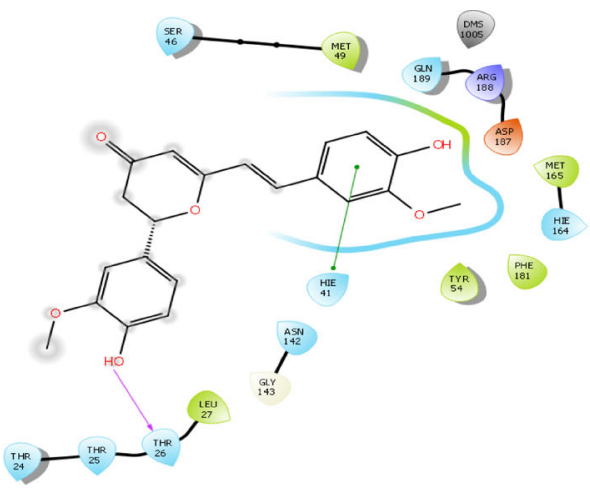

b Ligand Interaction of compound N1_Andrographolidewith SARS CoV-2 main protease (5R82)

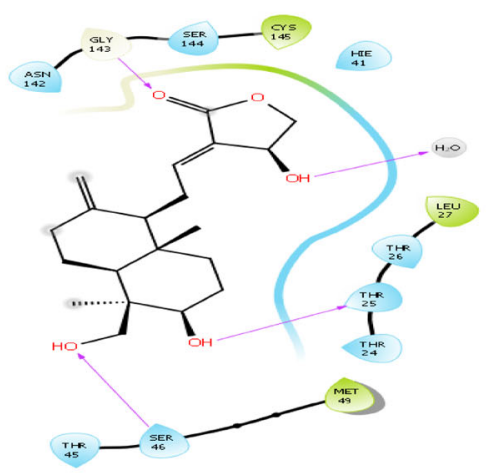

c Ligand Interaction of compound N7_dihydroxydimethoxyflavonewith SARS CoV-2 main protease (5R82)

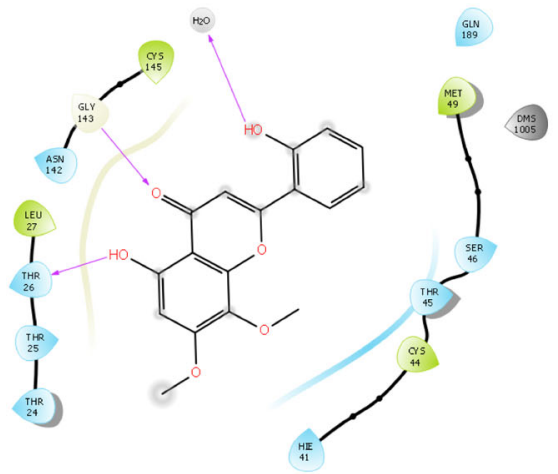

d Ligand Interaction of compound T1_Curcuminwith SARS CoV-2 main protease (5R82)

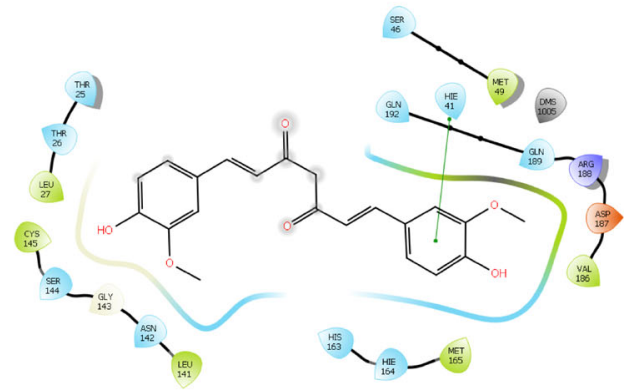

e Ligand Interaction of compound Hydroxychloroquine (Std) with SARS CoV-2 main protease (5R82)

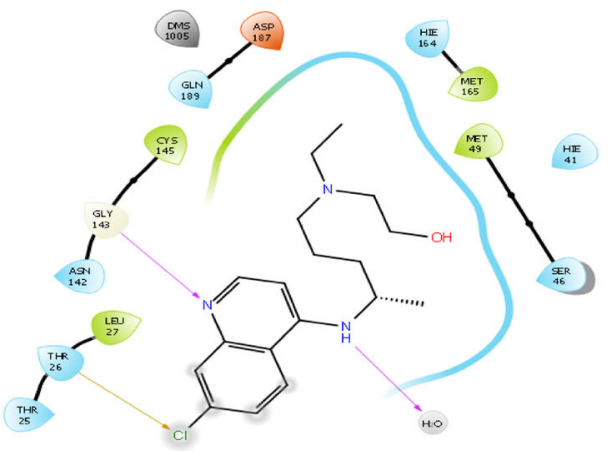

Fig. 3 a Ligand interaction of compound T4_Cyclocurcuminwith SARS CoV-2 main protease (5R82). b Ligand interaction of compound N1_Andrographolidewith SARS CoV-2 main protease (5R82). c Ligand interaction of compound N7_dihydroxydimethoxyflavonewith SARS CoV-2 main protease (5R82). d Ligand interaction of compound T1_Curcumin with SARS CoV-2 main protease (5R82). e Ligand interaction of compound hydroxychloroquine (Std) with SARS CoV-2 main protease (5R82) 


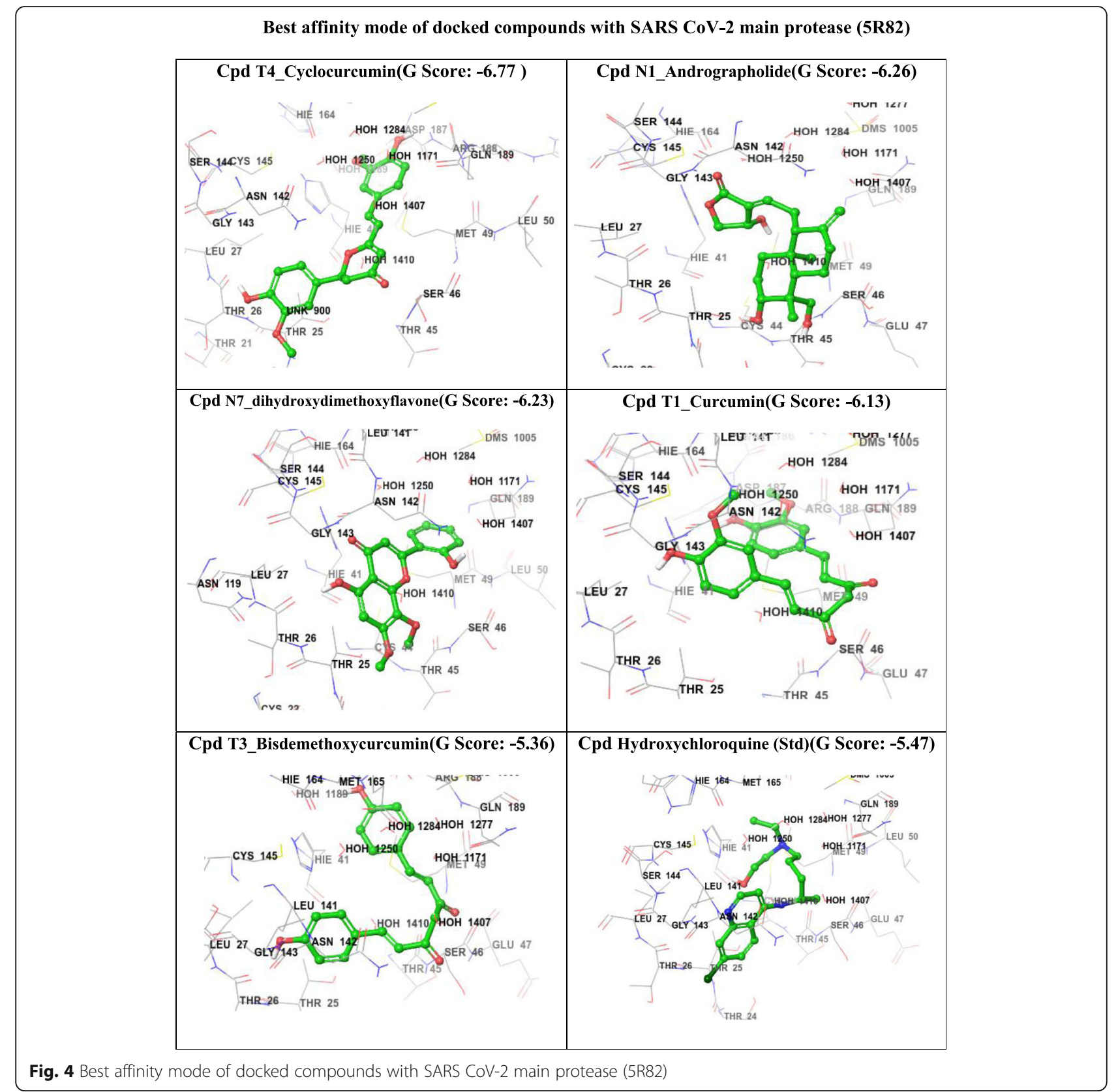

dimethoxy flavone significantly bind with the active site of COVID-19 main protease with Glide score more than -6 when compared to the currently recommended drug hydroxychloroquine (G score - 5.47) and significantly inhibit SARS CoV-2 main protease and may be active against COVID-19 on further process. The above compounds have good affinity to the receptor due to more lipophilic character and also due to hydrogen bonding. From the 2D-ligand interaction diagrams, almost all the compounds exhibited similar mode of interactions with SARS CoV-2 main protease and the residues THR24, THR25, THR26, LEU27, SER46, MET49, HIE41, GLN189, ARG188,
ASP187, MET165, HIE164, PHE181, and THR54 play a crucial role in binding with ligands.

From Fig. 5, the docking score of the ligand N1_Andrographolide is increased due to hydrogen bonding interaction with SER46 (H-bond length $3.45 \AA$ ), GLY143 (Hbond length $2.72 \AA$ ), and THR25 (H-bond length $1.90 \AA$ ) residues and with some water molecules. From Fig. 6, it is clearly demonstrated that most of the aromatic features are covered in the lipophilic region (red color) which contributed towards lipophilic factors.

From Fig. 7, the Glide score of the standard hydroxychloroquine is decreased because of the rotational 


\section{Hydrogen bonding interaction ofcpd N1_Andrographolidewith SARS CoV-2 main} protease (5R82)

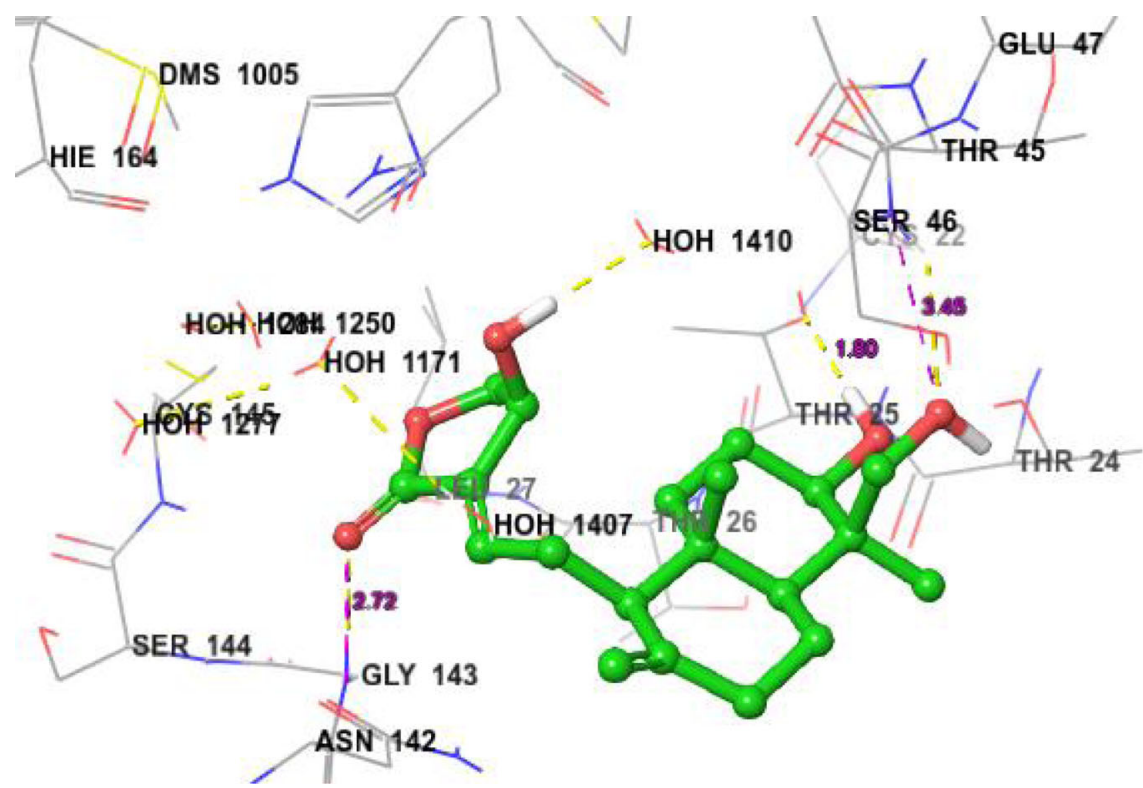

Fig. 5 Hydrogen bonding interaction of cpd N1_Andrographolide with SARS CoV-2 main protease (5R82)

penalty due to the rotation of the side alkyl side chain present at the fourth position of quinoline.

From the results of MM-GB/SA studies, the dG bind values were observed in the range of -34.6766 (N1_Andrographolide) to $-50.69 \mathrm{kcal} / \mathrm{mol}$ (N7_dihydroxy dimethoxy flavone) for significantly active compounds and also dG vdw values, dG lipophilic values, and the energies are positively contributing towards total binding energy. The accuracy of docking is confirmed by examining the lowest energy poses predicted by the scoring function. The Glide score and MM-GBSA free energy obtained by the docking of ligands into the coupling pocket are more stable.

Hydrophilic/lipophilic map of cpdT4_Cyclocurcuminwith SARS CoV-2 main

protease (5R82)

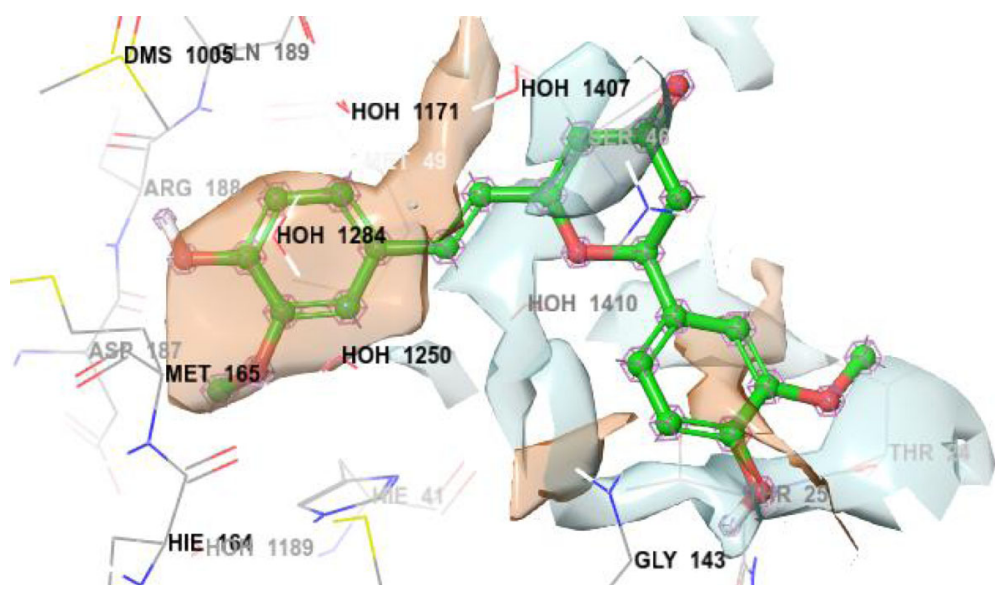

Fig. 6 Hydrophilic/lipophilic map of cpd T4_Cyclocurcumin with SARS CoV-2 main protease (5R82) 
(5R82)

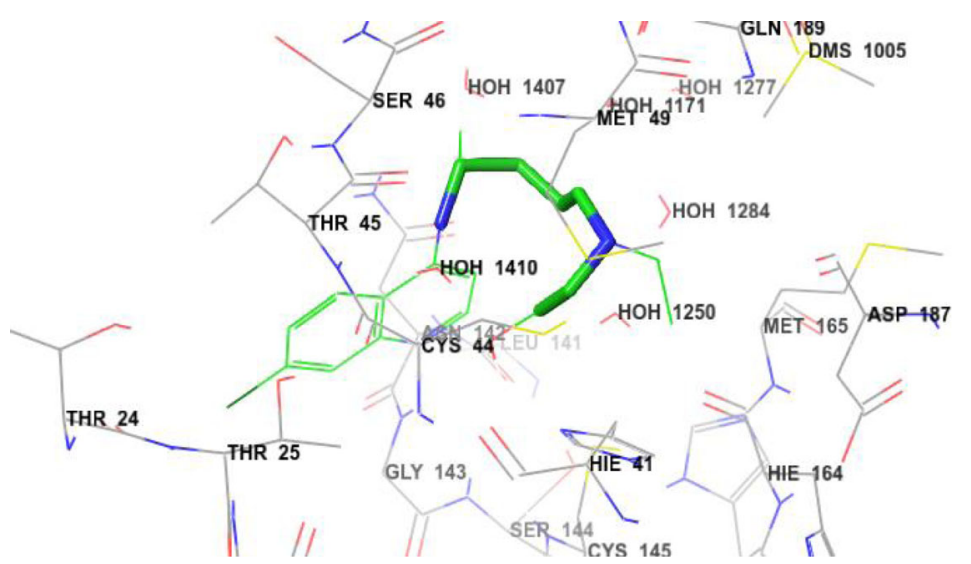

Fig. 7 Rotational penalty of hydroxychloroquine (Std) with SARS CoV-2 main protease (5R82)

\section{Conclusion}

From the results of the docking study, the chemical constituents of Curcuma longa (turmeric) and Andrographis paniculata demonstrated better arrangement at a dynamic site. The in silico structuring strategy embraced in the present investigation helped for recognizing some lead molecules and furthermore may somewhat clarify their useful impact for further determinations like in vitro and in vivo assessments. Results from the in silico study exhibited that many of the chemical constituents from Curcuma longa (turmeric) and Andrographis paniculata family may be useful against COVID-19 by inhibiting SARS CoV-2 main protease enzyme. Based on in silico studies, the chemical constituents such as cyclocurcumin and curcumin from turmeric and andrographolide and dihydroxy dimethoxy flavone from Andrographis paniculata are significantly active against COVID-19 by inhibiting SARS CoV-2 main protease enzyme with remedial possibilities and are probably going to be helpful after further refinement. In conclusion, consuming turmeric in our diet regularly may be a useful remedy in the prevention of the coronavirus.

\section{Abbreviations}

COVID-19: Coronavirus disease 2019; MM-GBSA: Molecular mechanicsgeneralized Born surface area; PDB: Protein data bank; OPLS3: Optimized potentials for liquid simulations; XP: Extra precision

\section{Acknowledgements}

The authors express their sincere gratitude to JSS Academy of Higher Education \& Research, Mysuru and also thank the principal Dr. S.P. Dhanabal, JSS College of Pharmacy, Ooty, for the technical support.

\section{Authors' contributions}

The authors KR and GB contributed to the technical and preparation of the manuscript. PV and BA contributed to the collection of literature and preparation of the manuscript. All authors have read and approved the manuscript and ensure that this is the case.
Funding

Not applicable/no funding was received.

Availability of data and materials

All data and material are available upon request.

Ethics approval and consent to participate

Not applicable

\section{Consent for publication}

Not applicable

\section{Competing interests}

The authors have no competing interests to declare.

Received: 23 April 2020 Accepted: 4 October 2020

Published online: 16 October 2020

\section{References}

1. Wang D, Hu B, Hu C, Xiong, Zhao, Li, Wang X, Peng (2020) Clinical characteristics of 138 hospitalized patients with 2019 novel coronavirus-infected pneumonia in Wuhan, China. JAMA. 323(11):1061-1069. https:/doi.org/10.1001/jama.2020.1585

2. Holshue ML, DeBolt C, Lindquist S, Lindquist S, Lofy KH, Wiesman J, Bruce H, Spitters C, Ericson K, Sara Wilkerson MN, Tural A, Diaz G, Cohn A, Fox LA, Patel A, Gerber SI, Kim L, Tong S, Lu X, Lindstrom S, Pallansch MA, Weldon WC, Biggs HM, Uyeki TM, Pillai SK (2020) First case of 2019 novel coronavirus in the United States. N Engl J Med. https://doi.org/10.1056/NEJMoa2001191

3. Zhou Y, Hou Y, Shen J, Huang Y, Martin W, Cheng F (2020) Network-based drug repurposing for novel coronavirus 2019-nCoV/SARS-CoV-2. Cell Discov 6:14-18

4. Gu J, Han B, Wang J (2020) COVID-19: gastrointestinal manifestations and potential fecal-oral transmission. Gastroenterology. https://doi.org/10.1053/j. gastro.2020.02.054

5. Calisher C, Carroll D, Colwell R, Corley RB, Daszak P, Drosten C, Enjuanes L, Farrar J, Field H, Golding J (2020) Statement in support of the scientists, public health professionals, and medical professionals of China combatting COVID-19. Lancet. 395(10226):e42-e43

6. To KK-W, Tsang OT-Y, Yip CC-Y, Chan K-H, Wu T-C, Chan JM-C, Leung W-S, Chik TSH, Choi CY-C, Kandamby DH (2020) Consistent detection of 2019 novel coronavirus in saliva. Clin Infect Dis 71(15):841-843. https//doi.org/10.1093/cid/ciaa149

7. Lu R, Zhao X, Li J, Niu P, Yang B, Wu H, Wang W, Song H, Huang B, Zhu N, Bi Y, Ma X, Zhan F, Liang W, Hu T, Zhou H, Hu Z, Zhou W, Zhao L, Chen J, Meng Y, Wang J, Yang L, Yuan J, Xie Z, Ma J, Liu WJ, Wang D, Xu W, Holmes EC, Gao GF, Wu G, Chen W, Shi W, Tan W (2020) Genomic characterisation and epidemiology of 2019 novel coronavirus: implications 
for virus origins and receptor binding. Lancet. https://doi.org/10.1016/ S0140-6736(20)30251-8

8. Zhou P, Yang X-L, Wang X-G, Hu B, Zhang L, Zhang W, Si H-R, Zhu Y, Li B, Huang C-L, Chen H-D, Chen J, Luo Y, Guo H, Jiang R-D, Liu M-Q, Chen Y, Shen X-R, Wang X, Zheng X-S, Zhao K, Chen Q-J, Deng F, Liu L-L, Yan B, Zhan F-X, Wang Y-Y, Xiao G-F, Shi Z-L (2020) A pneumonia outbreak associated with a new coronavirus of probable bat origin. Nature. 579:270273. https://doi.org/10.1038/541586-020-2012-7

9. Huang Q, Herrmann A (2020) Fast assessment of human receptor-binding capability of 2019 novel coronavirus (2019-nCoV). Bio Rxiv. https://doi.org/ $10.1101 / 2020.02 .01 .930537$

10. Zhang H, Kang Z, Gong H, Xu D, Wang J, Li Z, Cui X, Xiao J, Meng T, Wang Z, Liu J, Xu H (2020) The digestive system is a potential route of 2019-nCov infection: a bioinformatics analysis based on single-cell transcriptomes bioRxiv:927806. https://doi.org/10.1101/2020.01.30.927806

11. Chang, L., Yan,Y., Wang, L. (2020) Coronavirus disease 2019: coronaviruses and blood safety. Transfus Med Rev. https://doi.org/10.1016/j.tmrv.2020.02.003.

12. Huang, C., Wang, Y., Li, X., Ren, L., Zhao, J., Hu, Y. (2020) Clinical features of patients infected with 2019 novel coronavirus in Wuhan. China. Lancet. https://doi.org/10.1016/s0140-6736(20)30183-5.

13. Prakash P, Misra A, Surin WR, Jain M, Bhatta RS, Pal R (2011) Anti-platelet effects of Curcuma oil in experimental models of myocardial ischemiareperfusion and thrombosis. Thromb Res 127:111-118. https://doi.org/10. 1016/j.thromres.2010.11.007

14. Kuroda M, Mimaki Y, Nishiyama T, Mae T, Kishida H, Tsukagawa K (2005) Hypoglycemic effects of turmeric (Curcuma longa L. Rhizomes) on genetically diabetic KK-A $A^{y}$ mice. Biol Pharm Bull 5:937-939

15. Aggarwal BB, Kumar A, Bharti AC (2003) Anticancer potential of curcumin: preclinical and clinical studies. Anticancer Res 23(1A):363-398

16. Parthasarathy VA, Chempakam B, Zachariah TJ (2008) Chemistry of spices. United Kingdom. CABI:445-447

17. Haddad M, Sauvain M, Deharo E (2010) Curcuma as a parasiticidal agent: a review. Planta Med 77:672-678. https://doi.org/10.1055/s-0030-1250549

18. Abe Y, Hashimoto S, Horie T (1999) Curcumin inhibition of inflammatory cytokine production by human peripheral blood monocytes and alveolar macrophages. Pharmacol Res 39(1):41-47

19. Gupta B, Ghosh B (1999) Curcuma longa inhibits TNF-alpha induced expression of adhesion molecules on human umbilical vein endothelial cells. Int J Immunopharmacol 21(11):745-757

20. Srivastava R, Dikshit M, Srimal RC, Dhawan BN (1985) Anti-thrombotic effect of curcumin. Thromb Res 40(3):413-417

21. Bhatia A, Singh GB, Khanna NM (1964) Effect of curcumin, its alkali salts and Curcuma longa oil in histamine-induced gastric ulceration. Indian J Exp Biol 2:158-160

22. Ramirez-Tortosa MC, Mesa MD, Aguilera MC, Quiles JL, Baro L, RamirezTortosa CL, Martinez-Victoria E, Gil A (1999) Oral administration of a turmeric extract inhibits LDL oxidation and has hypocholesterolemic effects in rabbits with experimental atherosclerosis. Atherosclerosis 147(2):371-378

23. Kim DS, Park SY, Kim JK (2001) Curcuminoids from Curcuma longa L. (Zingiberaceae) that protect PC12 rat pheochromocytoma and normal human umbilical vein endothelial cells from betaA(1-42) insult. Neurosci Lett 303(1):57-61

24. Boopathi C (2000) Andrographis spp.: a source of bitter compounds for medicinal use. Anc Sci Life 19(3-4):164-168

25. Jarukamjorn K, Nemoto N (2008) Pharmacological aspects of Andrographis paniculata on health and its major diterpenoid constituent andrographolide. J Health Sci 54(4):370-381

26. Kabir MH, Hasan N, Rahman MM, Khan JA, Hoque NT, Quddus Bhuiyan MR, Mou SM, Jahan R, Rahmatullah M (2014) A survey of medicinal plants used by the Deb barma clan of the Tripura tribe of Moulvibazar district, Bangladesh. J Ethnobiol Ethnomed 10(1):19

27. Borhanuddin M, Shamsuzzoha M, Hussain AH (1994) Hypoglycaemic effects of Andrographis paniculata Nees on nondiabetic rabbits. Bangladesh Med Res Counc Bull 20(1):24-26

28. Akbar S (2011) Andrographis paniculata: a review of pharmacological activities and clinical effects. Altern Med Rev 16(1):66-77

29. Chaturvedi GN, Tomar GS, Tiwari SK, Singh KP (1983) Clinical studies on Kalmegh (Andrographis paniculata Nees) in infective hepatitis. J Int Inst Ayurveda 2:208-211

30. Dua VK, Ojha VP, Roy R, Joshi BC, Valecha N, Devi CU et al (2004) Antimalarial activity of some xanthones isolated from the roots of Andrographis paniculata. J Ethnopharmacol 95:247-251

31. Parichatikanond W, Suthisisang C, Dhepakson P. Herunsalee A (2010) Study of anti-inflammatory activities of the pure compounds from Andrographis paniculata (Burm.f.) Nees and their effects on gene expression. Int Immunopharmacol 10:1361-1373

32. Jade SR, Suburb GS, Matthews C, Hamzah AS, Lapis NH, Saad MS (2007) Semisynthesis and in vitro anticancer activities of andrographolide analogues. Phytochem 68:904-912

33. Husen R, Pihie AH, Nallappan M (2004) Screening for antihyperglycaemic activity in several local herbs of Malaysia. J Ethnopharmacol 95:205-208

34. Kalirajan R, Mohammed rafick MH, Sankar S, Gowramma B (2018) Green synthesis of some novel chalcone and isoxazole substituted 9anilinoacridine derivatives and evaluation of their antimicrobial and larvicidal activities. Indian J Chem 57B:583-590

35. Kalirajan R, Muralidharan V, Jubie S, Sankar S (2013) Microwave assisted synthesis, characterization and evaluation for their antimicrobial activities of some novel pyrazole substituted 9-anilino acridine derivatives. Int J Health Allied Sci 2(2):81-87

36. Kalirajan R, Muralidharan V, Jubie S, Gowramma B, Gomathy S, Sankar S, Elango K (2012) Synthesis of some novel pyrazole substituted 9anilinoacridine derivatives and evaluation for their antioxidant and cytotoxic activities. J Heterocyclic Chem 49:748-754

37. Kalirajan R, Mohammed rafick MH, Jubie S, Sankar S (2012) Docking studies, synthesis, characterization and evaluation of their antioxidant and cytotoxic activities of some novel isoxazole substituted 9-anilinoacridine derivatives. Sci World J:165258. https://doi.org/10.1100/2012/165258

38. Kalirajan R, kulshrestha V, Sankar S, Jubie S (2012) Docking studies, synthesis, characterization of some novel oxazine substituted 9-anilinoacridine derivatives and evaluation for their anti-oxidant and anticancer activities as topo isomerase II inhibitors. Eur J Med Chem 56:217-224

39. Kalirajan R, Rathore L, Jubie S, Gowramma B, Gomathy S, Sankar S (2011) Microwave assisted synthesis of some novel pyrazole substituted benzimidazoles and evaluation of their biological activities. Indian J Chem 50B:1794-1801

40. Kalirajan R, Sankar S, Jubie S, Gowramma B (2017) Molecular docking studies and in-silico ADMET screening of some novel oxazine substituted 9-anilinoacridines as topoisomerase II inhibitors. Indian J Pharm Educ Res 51(1):110-115

41. Kalirajan R, Gowramma B, Jubie S, Sankar S (2017) Molecular docking studies and in silico ADMET screening of some novel heterocyclic substituted 9anilinoacridines as topoisomerase II inhibitors. JSM Chem 5(1):1039-1044

42. Kalirajan R, Gaurav K, Pandiselvi A, Gowramma B, Sankar S (2019) Novel thiazine substituted 9-anilinoacridines: synthesis, antitumour activity and structure-activity relationships. Anti-Cancer Agents Med Chem 11:13501358. https://doi.org/10.2174/1871520619666190408134224

43. Kalirajan R, Vivek kulshrestha, Sankar, S. (2018) Synthesis, characterization and evaluation for antitumour activity of some novel oxazine substituted 9anilinoacridines and their 3D-QSAR studies. Indian J Pharm Sci 80(5):921-929

44. Kalirajan R, Pandiselvi A, Gowramma B, Balachandran P (2019) In-silico design, ADMET screening, MM-GBSA binding free energy of some novel isoxazole substituted9-anilinoacridines as HER2 inhibitors targeting breast cancer. Curr Drug Res Rev 11(2):118-128

45. Sastry GM, Adzhigirey M, Day T, Annabhimoju R, Sherman W (2013) Protein and ligand preparation: parameters, protocols, and influence on virtual screening enrichments. J Comp Aided Mol Design 27:221-234

46. Jacobson MP, Pincus DL, Rapp CS, Day TJF, Honig B, Shaw DE, Friesner RA (2004) A hierarchical approach to all-atom protein loop prediction. Proteins 55:351-367

47. Friesner RA, Murphy RB, Repasky MP, Frye LL, Greenwood JR, Halgren TA, Mainz DT (2006) Extra precision glide: docking and scoring incorporating a model of hydrophobic enclosure for protein-ligand complexes. J Med Chem 49:6177-6196

48. Li J, Abel R, Zhu K, Cao Y, Zhao S, Friesner RA (2011) The VSGB 2.0 model: a next generation energy model for high resolution protein structure modelling. Proteins 79:2794-2812

49. Cross R (2020) Chloroquine's use to treat COVID-19 is backed by US government, but many questions remain. Drug Dev 98(12)

\section{Publisher's Note}

Springer Nature remains neutral with regard to jurisdictional claims in published maps and institutional affiliations. 